Ivana M. Krsmanović

University of Kragujevac

Faculty of Technical Sciences Čačak

Čačak, Serbia

\title{
ENGINEERING STUDENTS' ATTITUDES TOWARDS COMPUTER-ASSISTED LANGUAGE LEARNING IN EFL
}

\begin{abstract}
With a promise of high efficiency, computer-assisted language learning (CALL) has become a much-exploited teaching approach in teaching English as a foreign language (EFL). The use of computers to assist language learners in their studies has shifted from being an innovative approach sporadically applied by an engaged teacher, to becoming the inevitable segment of in-class activities, nowadays almost prescriptively built in syllabi. Attitudes towards CALL constantly re-shape the learning process and affect the learning outcomes. The study addresses engineering students' attitudes towards the use of computer-assisted language learning in EFL courses taught at the Faculty of Technical Sciences Čačak in Serbia. The study is also concerned with the students' attitudes towards the use of the website www.englit.net as an online learning tool specially designed for the courses they attend, which is used on a regular basis for in-class practice and selfstudy. The findings indicate that CALL is perceived as an efficient supporter of the EFL teaching-learning process, generally adding to students' overall improvement in EFL competence, while at the same time empowering them to engage more in self-study.
\end{abstract}

Key words: EFL, Computer-assisted language learning, attitudes, engineering

E-mail address: ivana.krsmanovic@ftn.kg.ac.rs 


\section{Introduction}

Given that there are 743 million non-native speakers of English around the world (Eberhard et al. 2020), English is not only the most dominant language in business and science, but the most commonly "learned" foreign language around the world, and things will probably not change dramatically in years to come. Teaching English as a foreign language (EFL), which refers to the specialized field of language teaching designed for those whose primary language is not English, has come a long way from the initial baby-steps instruction based on the triangular "teachertextbook-student" concept to the most advanced teaching approaches available in the $21^{\text {st }}$ century.

Nowadays, EFL publishers regularly make sure that their textbooks are either accompanied by multimedia and/or a CD, or that printed issues are additionally enriched by online extensions of their courses. In that sense, Chapelle makes a great point when she asserts that "today almost anyone who is working on materials for classroom language learning is working in CALL" (Chapelle 2010: 67). CALL owes its tremendous popularity with students of all ages to, on the one hand, both students and teachers who are moving from being mere users of technology with basic functional literacy to rhetorical literacy in which they become producers of technology with a high level of digital skills.

On the other hand, rapid technological advances have dispelled a common misconception that computers are primarily for scientific or business use, so the everyday use of easily-accessed tools and applications for education is what we may refer to as a phenomenon of electronic democracy - equal language learning opportunity for all, unrestricted digital inclusion and active engagement in a process for which everyone is eligible. Consequently, the use of computers for entertainment or communication has given rise to the field known as "edutainment" (Beatty 2010: 189), used to denote teaching contents with entertainment value, often quite interactive, a growing industry of its own.

With the advent of technology, we are experiencing the pervasiveness of gadgets with significant educational potential. Such trends are rightly dictated by those who are being born in the age of the digital revolution, usually referred to as "Digital Natives" or "millennials" (Vukićević-Đorđević 2015: 486), who are familiar with computers from an early age, and whose educational matrix is exclusively inclusive of technology. Additionally, 
invaluable growth of educational technology is based on the fact that "technology is seen as an amplifier of cognition" (Vukićević-Đorđević 2015: 493), which has drastically changed the teaching process itself and all the parties affected, thus bringing new opportunities and challenges for students and practitioners.

\section{Computer-assisted language learning and EFL}

The term Computer-assisted language learning (CALL), which was adopted at the 1983 TESOL conference in Canada (Zhang 2011: 4), broadly defined, denotes "any process in which a learner uses a computer and, as a result, improves his or her language" (Beatty 2010: 7). It is a subfield of applied linguistics that deals with the use of technology in the teaching-learning processes in EFL (Rahimi 2015: xxi). However, due to rapid changes in technology which have enriched the field, scholars suggest a revision of the term, so a definition of CALL should be expanded to include, besides computers, "a variety of technology used for language learning" (Chapelle 2010: 66), that is, all the related networks connections and many other technological devices and applications, while the "improvement" of a language refers to learning efficiency and effectiveness, motivation and material access (Hubbard 2009: 2). Although CALL is a multi-disciplinary field at the intersection of disciplines - torn between very different traditions - sciences, social sciences and education (Stickler and Hampel 2015: 383), it has its origins in the development of the first mainframe computers and their application in language education in the 1980s. Throughout all the 3 stages in its development (Behaviouristic/Structural, Communicative, Integrative and Interactive) (Warschauer 2000; Yang 2010; Davies et al. 2017), CALL has changed dramatically, constantly adapting to novice and challenging technological advances, engaging many scholars and language practitioners to better fine-tune its classroom implementation to enhance language learning, and make it more productive, but less time-consuming. CALL, which is an instructional technique, or a teaching tool, not a method, has taken over classrooms all over the world, causing tremendous changes in teaching methodologies. 


\subsection{Previous research in CALL - state of the art}

Since CALL has been constantly growing and expanding, it has clearly become a "frustrating field" (Hubbard 2009: 1) both for scholars and ESL practitioners. As a dynamic field, CALL has brought many challenges to practitioners, yet, one of the most significant points was elaborated in the EUROCALL 2010 Research Policy Statement; since keeping pace with emerging tech trends is a never-ending, time-consuming process, it is necessary to shift the CALL focus from exploring the availability of new technology to developing language pedagogies related to it (Đorđević and Blagojević 2017: 248). Accordingly, more diverse research into how to make the best use of it is a core concept for the future of CALL.

In recent research on CALL, CALL-ists have advocated numerous benefits in surpassing the "chalk-and-talk" teaching method in which CALL appears as an effective supporter of a student-centered teaching/learning approach. Recent research has provided evidence of CALL fostering learner autonomy and helping learners adapt learning to their own pace and needs (Ali Ghufron and Nurdianingsih 2021; Rachmawati et al. 2020; Ismaili 2014; Vasbieva and Saienko 2018). In addition, many studies have shown that CALL enhances increased motivation and enjoyment to learners (Đorđević 2020; Rachmawati et al. 2020; Asrifan et al. 2020; Ismaili 2014; Afshari et al. 2013; Lockley and Promnitz-Hayashil 2012; Vasbieva and Saienko 2018), boosts the learning process (Kremenska 2007; Demirdöken 2019; Vasbieva and Saienko 2018), allows revisiting on numerous occasions and flexibility in using learning materials due to no time restrictions for users (Beatty 2010; Demirdöken 2019) both for practice and further study. Additionally, CALL has a proven track record in providing benefits when it comes to improving learners' vocabulary (Farahnia and Khodi 2017; Sadaghatkar 2018), grammar (Ghorbani and Ebadi 2020; AbuSeileek and Rabab'ah 2007), listening skills (Bontha 2016), writing skills (Ali Ghufron and Nurdianingsih 2021; AbuSeileek and Abualsha'r 2014; Kremenska 2007), overall proficiency (Delibegović and Hasanspahić 2020) while it is also promoting a higher level of interaction (Rachmawati et al. 2020; Afshari et al. 2013; Vasbieva and Saienko 2018). What is more, CALL is, reportedly, a rich source of authentic oral models of language (songs, podcasts, e-books), not restricted to any particular age group. Scholars emphasize CALL's capacity to bring forth intercultural understanding (Kern, Ware, and Warschauer 2008), to influence learners' 
critical thinking skills (Bontha 2016; Ismaili 2014), and to increase their overall knowledge of global issues.

On the other hand, certain constraints of CALL have been widely debated; one of the most critical issues are learners' individual needs, the type of feedback they receive, and a level of trust in the available online materials. Additionally, it has already been emphasized that schools may lack funds for software or equipment implementation (Paul 2020; Tafazoli et al. 2018), whereas teachers may face various challenges in preparing teaching materials (Tafazoli et al. 2018), and instructors might also require additional (or constant) training or support (Vukićević-Đorđević 2015; Baskaran and Shafeeq 2015). Among the researchers who had negative viewpoints about CALL, some argued that CALL is a waste of time and money (Zhang 2011: 4), while others had concerns about computers being inadequate to provide a more natural language as teachers appear to be inexperienced to produce quality learning material (Levy 1997: 2). Moreover, recent studies reveal that practitioners' list of CALL disadvantages includes the cost of equipment, time-consuming preparation activities, and lack of teacher training and experience (Bani-Hani 2014). As some research also suggests that students do not use CALL as much as their teachers believe they do (Wiebe and Kabata 2010), students' attitudes can reflect the reality of utilization of computer technology-based EFL courses.

\subsection{Attitudes in CALL}

Addressing attitudes towards CALL of both teachers and students seems to be as significant as evaluating learners' language improvement, since attitudes allow us to predict people's behaviours in certain circumstances. For that reason, "attitude" is emphasized as a fundamental aspect of the teaching/learning process which directs and reshapes education. As a psychological phenomenon, an attitude is the way in which a person expresses either their favour or disfavour towards something or someone (Tafazoli et al. 2018: 40), or as Triandis (1980) puts it, an attitude is an opinion charged with emotion. In a broader sense, attitudes are related to affective factors (Foroozesh-nia 2015: 23; Afshari et al. 2013: 853), which are considered emotional factors that significantly affect learning (Foroozesh-nia 2015: 23), and along with many other factors (selfesteem, defence mechanisms, beliefs, emotional intelligence, anxiety etc.), attitudes in a certain way stem from motivation (Foroozesh-nia 2015: 8). 
Attitudes are of (1) affective, (2) behavioural, and (3) cognitive quality, and are strongly associated with achievement (Kao and Windeatt 2014: 3), so positive or negative attitudes can significantly affect learning outcomes. Given that attitudes possess a synergetic potential among the 3 of their listed qualities, attitudes as a positive or negative value that people assign to situations or objects significantly affect people's perception and channel their behaviour within different activities. Along with motivation and cognitive style, attitudes can be broadly categorized under "learner conceptualization" (Larsen-Freeman 2001) which, altogether, affect whether language learners perceive themselves as under-achievers or as competent as their peers. The influence of feelings and emotions, as well as displeasure and frustration, are as important as cognitive or mental abilities (Foroozesh-nia 2015: 8). In other words, a positive attitude (as a learned predisposition for responding favourably in a coherent way) is the desired feedback in learning, which makes the learning easier and fun, while a negative attitude (responding unfavourably) is perceived as a crucial barrier to accomplishing the learning goals.

As attitudes are learned predispositions, they are likely to be stable over time (Rahimi 2015: 9). Such quality of attitudes may greatly influence both slow and eager learners, in different directions, of course, since what links attitudes and behaviours is the assumption of consistency. In that context, what we might find an essential educational intervention is to be aware of the presence of negative attitudes with learners, to prevent their further deepening. Longer exposure to such attitudes may lead to continual repetition of negative trends in behaviour that might finally culminate with strong unfavourable behavioural patterns which could develop into a harmful educational matrix in the long run (over time). Fortunately, the predictive nature of attitudes can help us reassess and reshape the educational process to encourage a more positive attitude as the desired feedback.

A significant role of attitudes in EFL has been highlighted in many recent studies (Delibegović and Hasanspahić 2020; Paul 2020; Asrifan et al. 2020; Tsintavi 2017; Vasbieva and Saienko 2018; Afshari et al. 2013; Ismaili 2014; Zhang 2011). Demirdöken (2019) reported that an attitude towards CALL, as the most common constant variable for all learners, has been one of the most popular non-linguistic variables in the language learning environment (Demirdöken 2019: 2700), concluding that "language learning is highly dependent on the learner's attitude toward 
achieving the competency in the target language". In a large-sample study with 208 Chinese university students, Zhang found that students' attitudes toward CALL are a key factor for predicting the success in CALL (Zhang 2011), concluding that students who had more than 3 CALL-based courses had a more positive attitude towards CALL than those who received no CALL ESL course (Zhang 2011: 84). In the similar-context research with 94 students of informatics at a faculty in Bulgaria, the respondents expressed their overall satisfaction with a CALL-based course they had attended, with minor improvements suggested to the teacher related to the choice of ESP texts (Kremenska 2007). Likewise, a study on CALL with a sample of 100 Malayan students of Languages and Linguistics indicated that students had moderate attitudes towards CALL, while it also provided evidence that the key determinants of attitudes towards CALL are perceived usefulness (PU) and perceived ease of use (PEU) of computers (Afshari et al. 2013).

For a more comprehensive understanding of the phenomenon in the real in-class contexts, students' attitudes towards CALL have been researched in depth. However, diverse studies show disparate findings across similar-context studies for different aspects. For example, students' attitudes towards CALL, although overall positive, still reveal too wide a range of positive attitudes, starting from $98 \%$ as the highest result (Basheer 2013), to 97.8\% (Tsintavi 2017), then 91.9\% (Tafazoli et al. 2018), then 85\% (Vasbieva and Saienko 2018) or over 80\% (Lockley and PromnitzHayashi 2012), then 78\% (Ismaili 2014), to only 66\% in certain studies (Basheer 2013). Similarly, discrepancies are found in other CALL-related perceptions; for example, some studies revealed that students believe that CALL is equally helpful with all 4 language skills, with grammar being rated the highest and speaking the lowest (Shafaei 2012). However, in contrast to this, Kremenska (2007) found that within her scope and sample, grammar was improved "a little", with the lowest score, whereas speaking was the most improved skill, from the respondents' viewpoint. Similar inconsistencies are seen with differences in results for other CALL preferences across different studies; thus, as many as $84 \%$ of the students turn to the Internet while searching for the unknown word meanings (Vukićević-Đorđević 2015: 489), whereas similarly, in another study, $87.8 \%$ of the students also expressed their belief that the Internet has the advantage over books when looking for some information (Tsintavi 2017). However, Tsintavi found that percentage to be slightly lower in the similar-context research; using dictionaries online is preferred by $65.2 \%$ 
of the students. As for CALL at home vs. CALL at school preference, some studies suggest that $72.2 \%$ of the students prefer utilizing computers at school (Tsintavi 2017) with the most important advantage of such utilization being better equipment they have at schools (100\%), and with peer-cooperation being a highly valuable asset. On the other hand, slow or inconsistent internet connection and lack of technology-based instruction are reported as a common disadvantage when CALL application at schools is concerned (Vasbieva and Saienko 2018). However, contrary to this, Ismaili (2014) found that $68 \%$ of the students enjoy using computers outside the classroom, whereas, as another study reveals, homework assignments are what CALL is particularly useful for (Bontha 2016: 165).

What recent studies concur about is that there is clear evidence that CALL has radically changed teachers' role from being "dominators" to becoming "facilitators" (Vasbieva and Saienko 2018: 132). Recent findings also suggest that students feel that computers cannot substitute teachers (Tafazoli et al. 2018), and when students were asked to compare CALL to learning with teachers in a real setting (face-to-face), almost half of the respondents had negative or neutral attitudes towards CALL effectiveness (Demirdoken, 2019: 2702). These facts imply that attitudes are of the utmost importance in CALL as they affect the teaching/learning process and direct the process of ESL acquisition. To conclude, although the attitude studies received much attention in earlier studies, little research has been done into engineering students' perceptions of CALL, especially if they use a specially designed tool for learning English. This study aims at filling the gap in the current research and hopes to offer a fresh perspective that might be beneficial for both scholars and practitioners.

\section{Research Methodology}

This study is primarily concerned with students' attitudes towards CALL and, more specifically, to their utilization of the website www.englit.net as an online learning tool which is specially designed for the Englishbased courses they attend at the Faculty of Technical Sciences Čačak. The ENGLIT lab (comprising 20 computers with a fast Internet connection, access to the custom-made website www.englit.net), where the treatment and the research were conducted, was initially launched at the Faculty as the outcome of the project titled "Innovation in teaching English fostering 
IT skills and entrepreneurial potential with students" in 2018. The project was fully funded by the National Ministry of Education and Science. After the syllabi of 4 English-based courses (2 General English and 2 ESP courses) had been adapted for both face-to-face and online learning alternatively, the website www.englit.net was implemented as a supporting tool and updated on a daily basis, for in-class teaching and practice, and self-study. The material available on the website was used as teaching material for all the listed courses, regularly, every week for 2 semesters throughout the academic year 2019. Apart from the course-related materials, the website has been enriched by blogs, writing skills lectures, literature references. The project author (Ivana M. Krsmanović) is a website administrator, although other language teachers and students participate as contributors.

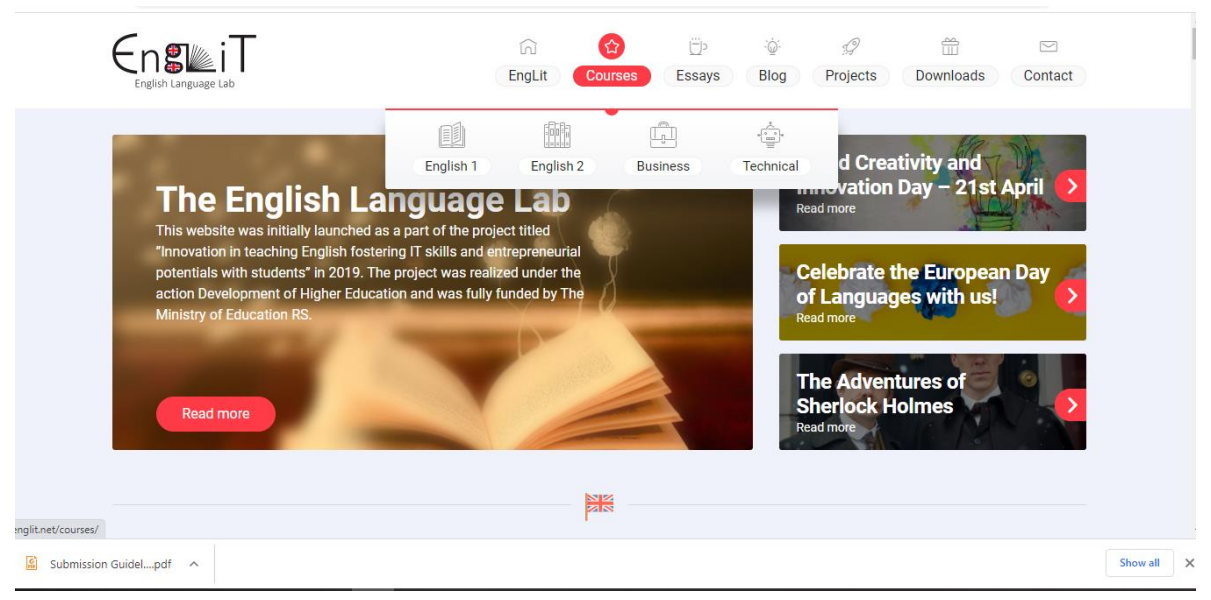

Figure 1. Englit.net website front page

\section{Research Questions}

The study seeks to address the following research questions and test the following hypotheses:

RQ1: What are the attitudes of engineering students towards the use of CALL? 
RQ 2: To what extent do engineering students find the website www.englit.net beneficial for improving their English language competence?

Hypothesis 1: Engineering students have positive attitudes towards the use of CALL.

Hypothesis 2: Engineering students find the website englit.net useful for improving their English language competence.

In order to answer the research questions adequately, the methodology and findings of recent research on CALL have been used to structure the current research design. As CALL is a multi-faceted and fast-changing activity, it cannot easily be captured with one research approach. However, exploratory approaches allow CALL researchers to study potentially new phenomena with an open mind (Stickler and Hamper 2015: 386). Instead of measuring the progress of individual learners in an experimental study with the help of a pre-test and post-test approach and associating results with the success or failure of a particular treatment, many researchers favour examining learners in their context (Stickler and Hamper 2015: 389). As for the specific research focus, Chapelle (2003) distinguishes three types of research in CALL: with a focus on (1) software, (2) on the learning task or task pedagogy, and (3) on the learners. Having considered all of the above, the purpose of this study is exploratory, the research approach is a survey, and the study focuses on the learners.

\subsection{Research method}

The current study was conducted at a state faculty in Čačak, Serbia, in December 2019. The participants were selected by using criterion sampling, as a part of the purposeful sampling method (Patton 2014). The sample criteria were: all the participants in the study were active students who (1) have attended and passed at least one course in English (out of 4), (2) have used the website www.englit.net in classes or at home. A qualitative method with the use of quantitative measures was chosen as the most adequate for the study. Since there is no appropriate instrument to measure students' attitudes towards CALL, the researcher developed an original questionnaire, taking into account the questionnaires designed 
for the research with similar purposes (Ismaili 2014; Demirdöken 2019; Tsintavi 2017; Bontha 2016; Al Shammari 2007). All students have access to computers and the Internet either at home or at the college, the majority of them both.

Upon the completion of the courses (which correlates with the treatment), a 2-section survey questionnaire (given in the Appendix) was administered to the participants who volunteered for this study and were assured of the confidentiality of their responses. Questions regarding personal information were eliminated. The instrument was composed of 15 statements related to CALL (closed-item), 10 of which were related to general attitudes towards CALL (the first section), and 5 of which were statements related to the website www.englit.net (the second section). To the first three questions (questionnaire section 1) the participants evaluated statements on a 5-point Likert scale, ranging from 1 (wherein 1 corresponds to "never") to 5 (wherein 5 corresponds to "always"). One question in the first section was a multiple choice question (allowing the respondents to choose a maximum of 3 options), while 6 questions in the first section had two options to choose from; yes and no. The second section of the questionnaire consisted of 3 questions with two optional responses given (yes-no), and 2 questions offered multiple choice answers, allowing the respondents to choose more than one response. The online questionnaire, which was designed in Google Forms application and forwarded to the participants via e-mail, was previously reviewed by two experienced college lecturers of English, to ensure validity and reliability.

The sample of the study consisted of 108 undergraduate and postgraduate students. As for demography, among the respondents, $65.1 \%$ were male, while $34.9 \%$ were female. In terms of age, $55.6 \%$ were between 20 and 25 years old, $29.6 \%$ were younger than 20 , and $14.8 \%$ were older than 25 . As for the major they were studying at the college, $30.6 \%$ of respondents studied Mechanical engineering, 22.2\% studied Electrical engineering, $18.5 \%$ studied Information technology, $17.6 \%$ studied Graphic technology, and 11.1\% studied Production management and ecology. On average, each participant took less than 10 minutes to complete the questionnaire. 


\section{Results and discussion}

The first section of the questionnaire was aimed at investigating whether students used CALL on a regular basis. As many as $35.2 \%$ of the respondents admitted to having moderate CALL habits (grade 3 of the Likert Scale), while $31.5 \%$ admitted to using CALL at all times (question 1). Only 1.9 $\%$ of the respondents never used CALL. These results (Table 1) imply that almost $60 \%$ of the respondents (59.1\%) used CALL very frequently, namely always or often.

\begin{tabular}{|c|c|c|c|c|c|}
\hline Question & ..never & ..rarely & ...sometimes & ...often & ...always \\
\hline $\begin{array}{c}\text { 1. I use CALL... } \\
\begin{array}{c}\text { 2.When I } \\
\text { need grammar } \\
\text { instruction or a } \\
\text { word translation, } \\
\text { I use the } \\
\text { Internet... }\end{array}\end{array}$ & $1.9 \%$ & $13.9 \%$ & $35.2 \%$ & $17.6 \%$ & $31.5 \%$ \\
\hline $\begin{array}{c}\text { 3. I find the } \\
\text { answer I am } \\
\text { looking for on } \\
\text { the Internet on a } \\
\text { language learning } \\
\text { application... }\end{array}$ & $2.8 \%$ & $7.4 \%$ & $13.9 \%$ & $17.6 \%$ & $60.2 \%$ \\
\hline
\end{tabular}

Table 1. Attitudes towards CALL - distribution of responses for questions 1-3

The second question was aimed at exploring how much students relied on the Internet as a CALL resource for grammar instruction or a word translation. As for the statement "When I need grammar instruction or a world translation I use the Internet..." (never-always), the majority of the respondents admitted to always exploiting the Internet for such purposes (60.2\%), while, interestingly, none of them felt they never used the Internet for grammar or translation (0\%). As given in Figure 1 and Table 1, the percentage of students who often resorted to the Internet as a resource for grammar instruction or a word translation is $17.6 \%$, whereas only $8.3 \%$ of them rarely used the Internet for such a purpose. These findings reveal that the Internet seems to be the first choice for EFL instruction for almost 
$80 \%$ of the students, while $20 \%$ of the respondents feel that they search for language instruction elsewhere.

\section{When I need grammar instruction or a word translation I use the Internet}

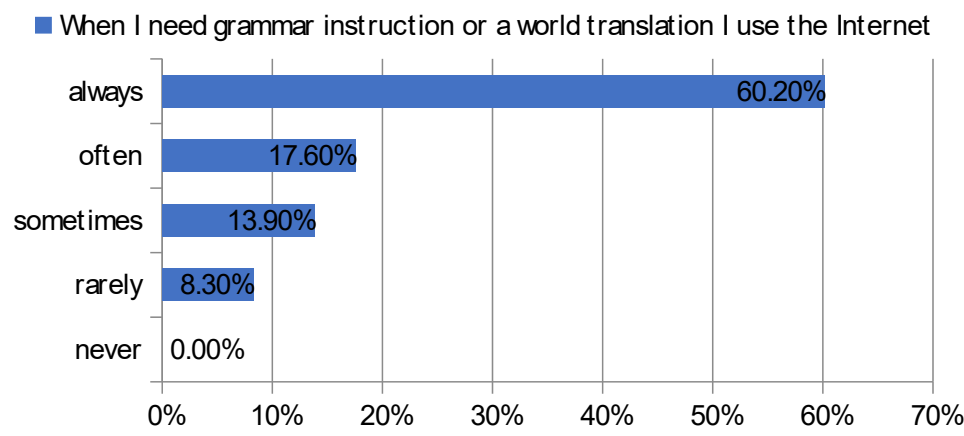

Figure 2. Students' frequency of using the Internet for studying English

Question 3 was designed to investigate how successful students were at finding what they were looking for, related to ESL and CALL as a medium of instruction. As shown in Figure 2, approximately one-third of the respondents $(35.2 \%)$ confessed that they did not always find the answers they were looking for on the Internet or within a language learning application, whereas only $24 \%$ of the students always found what they needed. As many as $10.2 \%$ of the respondents felt that their hunt for the desired content was not successful ("never"/"rarely" responses). These data imply that whereas $54.6 \%$ of the students find the material they are looking for within the CALL process, the other half of the respondents feel quite the opposite, which points to the conlusion that the frequent use of CALL does not guarantee that the actual learning is taking place. It rather indicates that a significant amount of time is wasted on the search for the needed content, or that there are distractions that interfere with the learning process (inadequate level of the target language, poor competencies in digital skills, prior knowledge etc). 


\section{I find the answer I am looking for ...}

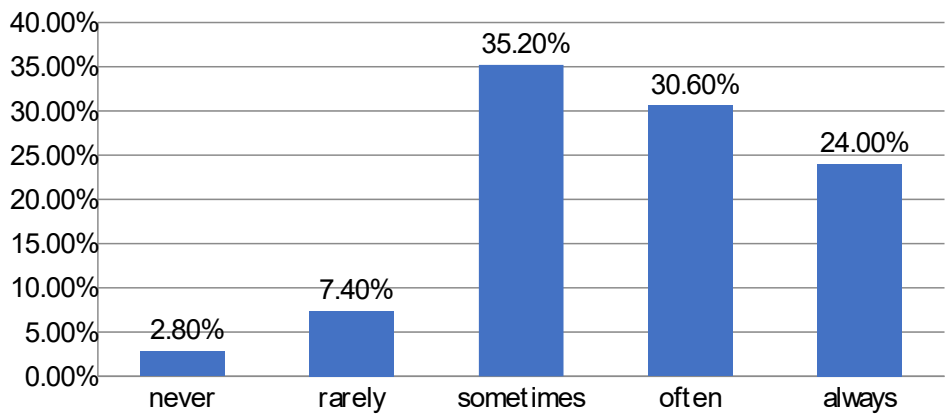

Figure 3. Students' perceived success at finding content in CALL

The fourth question of the first section was aimed at investigating students' attitudes towards the perceived usefulness of the CALL in their language improvement, and it was given in the form of a statement with 2 answers "yes" or "no". As many as $87 \%$ of the students believed that CALL could help them master the English language, whereas 13\% thought that was not the case (Figure 3 ). This suggests that students perceive technology as a highly-valuable tool in the learning process that can improve their ESL competencies.

\section{I believe I can improve my English with CALL.}

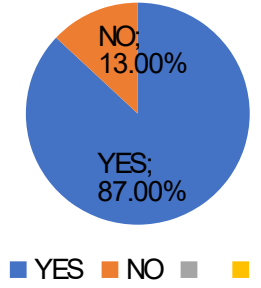

Figure 4. Students' attitudes towards the perceived usefulness of the CALL 
Questions 5 and 10 were designed to explore how students perceived a teacher's role in CALL. When they needed a word translation or help with some unclear grammar instruction (question 5), the students felt they could trust their teacher (88\%) rather than the information gained online $(12 \%)$. Interestingly, when asked whether they feel more anxious or afraid not to make a mistake in a face-to-face class compared to making mistakes in the CALL instruction (question 10), as many as $62 \%$ admitted that they were not more afraid or anxious when learning with a teacher. Yet, 38\% of the students felt more nervous when learning with a teacher rather than by a computer (Figure 4). Such a large percentage of responses in favour of teacher instruction suggests that teachers are still perceived as pillars of education with a pivotal role in the teaching-learning process, with their dominance not likely to be replaced by computers. In other words, although belonging to the 'Net Generation', students are not especially motivated by high-tech apps and tools when utilized for educational purposes. On the contrary, it seems that they are willingly abandoning the benefits of the Internet for a more traditional approach to teaching.

\section{I am more anxious or afraid not to make a mis- take in a face- to- face class compared to mak- ing mistakes in CALL instruction.}



Figure 5. Students' anxiety towards making mistakes in face-to-face instruction vs. CALL

The sixth question of the first section was designed to test students' preferences related to the type of CALL instruction they most enjoy having. Out of the 7 options offered; (1) YouTube, (2) Social Networks, (3) Mobile 
phone apps, (4) Websites for learning English, (5) Multimedia for learning English, (6) Newspapers, articles and blogs, (7) Games and quizzes, they were allowed to choose maximum 3. The most preferred CALL instruction was YouTube with $62 \%$, closely followed by Social Networks instruction (Facebook, Instagram, Twitter) with $41.7 \%$, while the third most popular choices were games and quizzes with $38 \%$. Websites for learning English were preferred by $34.3 \%$ of the respondents, mobile phone applications by $33,3 \%$, newspapers, articles and blogs were chosen by $24.1 \%$ of the students, and finally, multimedia for learning English was selected by only $17.6 \%$. These results (Figure 5) suggest that students are generally attracted to: 1) relatively short audio-visual content, themed or otherwise specially designed (such as YouTube videos); 2) up-to-date, instant communication platforms aimed at socializing and promotion (as in Twitter, Instagram and Facebook); 3) interactive and fun (on-line) activities which foster competitiveness and can be co-played with peers (for games and quizzes). These 3 top choices are interconnected with certain similarities; (1) they all belong to the social media field which broadcasts certain preprepared content, (2) they are easy and free to access online, (3) they are all available 24/7. Additionally, (4) all 3 top choices feature emerging trends in different communities, (5) include the audience of some kind (subscribers, followers, fellow players), and (6) can be re-visited and navigated on request. This supports the assumption that, due to its major impact on young people, popular culture is likely to determine and expand the educational pathways. Practitioners who can make popular culture a trusted ally in EFL teaching will, for obvious reasons, better meet the learning outcomes. 


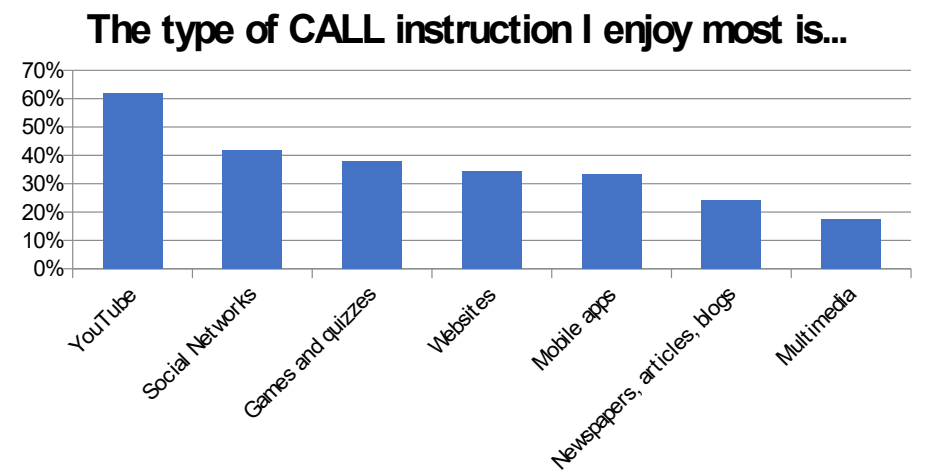

Figure 6. Students' preferences to the type of CALL they most enjoy

When asked (question 7) whether they enjoyed using CALL for in-class learning activities, 56.5\% confessed to enjoying it, whereas for the use of CALL for self-study activities or homework assignments at home or elsewhere (question 8) as many as $78.7 \%$ admitted to enjoying such activities. These responses suggest that students perceive CALL as an adequate tool for self-study while they still expect a traditional classroom to be face-to-face teaching.

Question 9 of the first section was aimed at assessing students' motivation to learn English related to the medium of instruction of the content ("I am more motivated to engage in self-study if the content is presented as computerized instruction than in the traditional way"). As many as $52.8 \%$ of the respondents were more motivated to learn if the content was given as computerized instruction while $48.1 \%$ were more motivated when using more traditional methods such as textbooks and printed dictionaries. These responses complement the previous conclusion; given that half of the respondents felt that a traditional educational setting with a language instructor and a textbook was more engaging, we can conclude that, based on these findings, non-computerized instruction and a face-to-face teaching approach still have a tremendous value for students.

The second part of the questionnaire were questions related to students' experience of using the website www.englit.net. Question 1 of the second section aimed at assessing students' motivation to commit to self-study if/when they use the website englit.net. As many as $63.9 \%$ of the respondents declared they were more motivated (with a significant level 
of autonomy) when learning English on englit.net. The second question dealt with the availability of materials related to exam preparation and it was given as a statement ("Englit.net helps me find the content I need for the exams (mock tests, mid-term exams, past examination papers"). A large percentage of the respondents (84.3\%) found the website helpful when looking for exam-related materials, while $15.7 \%$ thought the website was not helpful. Question 3 was aimed at exploring which improvements of the website students would find useful: out of 5 offered choices which refer to sections that could be implemented (quizzes and games, chat, forum, video lectures, audio lectures) students chose the top 3: (1) video lectures $(54.6 \%),(2)$ quizzes and games (32.4\%) and (3) audio lectures (30.6\%). "Forum" and "chat" were the least popular options with 10.2\% and $20.4 \%$, respectively. These findings (Figure 6) imply that students are not interested in communicative channels in which they can exchange ideas with colleagues, but they feel that seeing/hearing a teacher (like the most valuable digital replacement for a traditional teaching setting) in a target language would be the most beneficial.

\section{I would add these sections to the englit.net webisite}

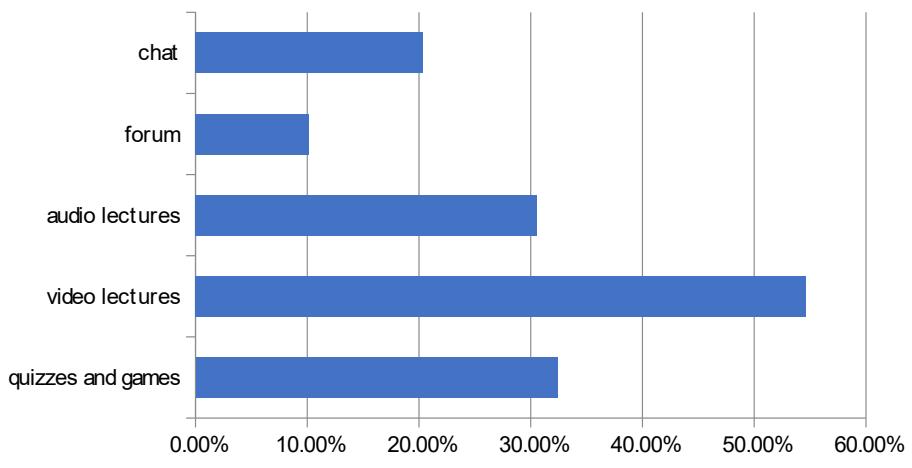

Figure 7. Students' preferences for adding new content on englit.net

Question 4 was "What do you like most about the website englit.net?" The offered responses included 7 items: (1) practice, (2) past exams, (3) essays and blogs, (4) material availability 24/7, (5) lectures on grammar rules, (6) video content, and (7) Twitter and an Instagram feed. The respondents were allowed to choose 3 items of their preference. Interestingly, as given 
in Figure 7, (7) Twitter and Instagram feed and (3) essays and blogs were the least liked, with $3.7 \%$ and $17.6 \%$, respectively. The most liked feature of the englit.net website was (1) material availability $24 / 7$ with $52.8 \%$, followed closely by (2) lectures on grammar rules with $50.9 \%$ and (3) practice with $50 \%$. The option "Past exam papers" also had a high score of $47.2 \%$, whereas the video content was not that liked (23.1\%).

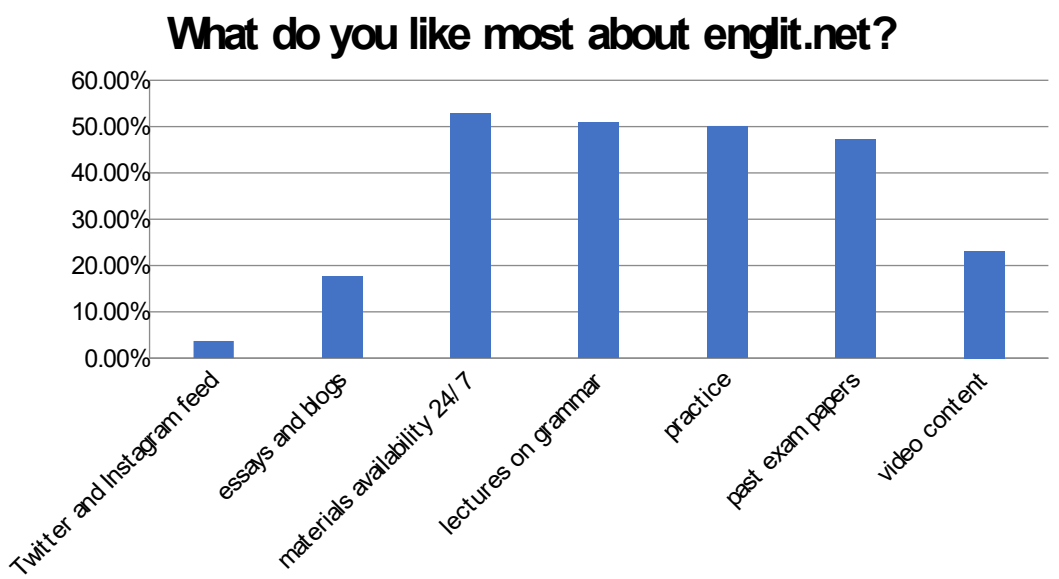

Figure 8. Students' preferences related to the offered content on englit.net

Several conclusions can be drawn based on these data. The first conclusion is that having content closely correlated with the lectures (textbook, mockexams, handouts) is highly valued by students. It is evident from these results that open access to the adapted, exam-related materials enhances learners' interest and bears great potential for students to engage more in self-study. Additionally, this indicates that students tend to clearly differentiate between leisure activities, such as Social networking, and the learning activities they partake in for exam preparation, so there is no perceived usefulness of Instagram or Twitter feeds on the englit.net website. Another observation stemming from these findings is related to video content. Despite the fact that $54.6 \%$ of the respondents suggested that video lectures should be implemented on the website (question 4), it is quite interesting that the existing video content on the website was liked only by $23.1 \%$ of them (question 3 ). These findings imply that while 
students highly value video content (54.6\%), website-featured videos are poorly rated since they are perceived as inadequate or unrelated to the syllabi. In our case, the video content available on the website was not language instruction but a selection of interesting TED talks, aimed at improving learners' listening for gist and critical thinking skills. To conclude, these data further reveal that the students' attitudes towards both learning material and social networks feeds are the same; whatever is perceived as "beyond" and "out of" syllabus content is regarded as incidental and unnecessary.

The last question of the section was a statement "Englit.net helps me to adapt the pace of learning to my personal needs (which lectures to study, when, how much)", which was to be evaluated with "yes" or "no". As many as $78.1 \%$ of the respondents chose "yes", while $21.9 \%$ chose "no" as their response. This implies that a custom-made website is perceived as a flexible learning tool that allows learners to overcome individual differences in learning, which might additionally affect success. Moreover, such a resource is perceived to increase learner independence.

\section{Conclusion}

Computer-assisted language learning, which has revolutionized the way English is taught, has been constantly re-purposed in the light of new and exciting discoveries in the field of teaching ESL. Although there is general consent that CALL's apparent benefits for learners include immediate feedback, self-pacing, privacy and learner autonomy, among others, some major constraints of CALL have also been experienced in real classroom settings. In the age of "Digital Natives" those drawbacks have been conditioned by the everyday abundance of various apps and gadgets whose effectiveness in a language learning process is even difficult to track, due to their being too easily and too quickly replaced and surpassed by new, more advanced ones. Recent studies suggest that what remains the main CALL limitation is extra expenses imposed upon universities to invest in the equipment, so more affordable technology is a clear demand for the future.

As CALL "has come of age" (Davies et al. 2017: 34), the CALL-ists' focus has shifted from expanding the CALL field overburdened with the advent of technology, to finding the best fit for CALL to be implemented in 
the real classroom contexts. Such a task seems to be equally challenging for both practitioners and learners since the pervasiveness of easily accessed gadgets and users' overdependence on technology interferes with their digital literacy skills and affects the teaching/learning outcomes. In order to come closer to the goal, it is advised to consult contemporary findings in pedagogy which rely upon the idea that "[c]urrent pedagogy advocates collaborative knowledge construction rather than simple instructivist learning, as well as authenticity and task orientation" (Davies et al. 2017: 33). With its tremendous potential in the field of English language acquisition, if used properly, with clear objectives and adapted to the learners' needs, CALL promises of efficiency are not questionable.

Students' self-reported perception or attitudes towards CALL, as important factors in learning success, can help additionally pinpoint the direction of CALL in which teachers are acknowledging the need for change in their practices to best support their classrooms. The findings from this study indicate several important implications of CALL in relation to students' attitudes. Firstly, $60 \%$ of the students use CALL very frequently. A high percentage of the students (87\%) believe that they can improve their English with CALL, however, 88\% of them trust their teacher more than online instruction. Almost equal distribution of responses is divided between traditional vs CALL instruction preference; namely, $52.8 \%$ of the respondents prefer CALL, whereas $48 \%$ prefer traditional classes. CALL is, as the findings of this study reveal, best utilized for homework assignments (78.7\%). Another observation is that, although $80 \%$ of the students rely on the Internet as a CALL resource for EFL instruction, they admit to enjoying face-to-face instruction more due to the fact that only $54.6 \%$ of them find the needed language content on the Internet. These data reveal that a conventional type of contact classes with the teachercentred authority is strongly emphasized and, accordingly, in relation to the Internet-based learning environment, the students feel that such an approach is more learner-friendly, anxiety-free or better supportive of their specific needs. As this research study shows, teachers are still perceived as the most reliable, ubiquitous form of delivering instruction. Yet, it must be emphasized, CALL features certain highly valued characteristics with learners; (1) it allows students to adapt their learning to their own pace (78.1\%), and (2) has a significant advantage (over traditional teaching) in providing learning materials $24 / 7$ (84.3\%). When it comes to social networks as a segment of CALL, they are strictly associated with leisure 
activities, and the same applies to video content - if a video is perceived as unrelated to the course syllabi, it is not enjoyed at all. Also, the students believe that forums/chats are a thing of the past, but they also feel that video lectures are what they would implement in a custom-made website (54.6\%). Finally, the study suggests that the ENGLIT lab experience has empowered engineering students to study and collaborate in a more interactive and intensive manner, which supports Beatty's idea that for collaboration at the computer to be successful, a supportive environment needs to be established (Beatty 2010: 165). On the basis of the foregoing results, the following conclusion seems to be justified: engineering students have positive attitudes towards the use of CALL and find the website www. englit.net useful for improving their English language competence. This infers that both the 1st and the 2nd hypotheses have been supported. The final remark of the study refers to our revisiting the definition of CALL, so that we must additionally highlight the adjective which constructs the concept itself. In other words, computer-assisted language learning is, as its name indicates, an approach assisted by computers, not guided by, and should remain so.

\section{References}

Abu Seileek, A. and A. Abualsha'r (2014). Using Peer Computer-mediated Corrective Feedback to Support EFL Learners' Writing. Language Learning \& Technology, 18 (1), 76-95.

AbuSeileek, A. and G. Rabab'ah (2007). The Effect of Computer-based Grammar Instruction on the Acquisition of Verb Tenses in an EFL Context. The JALT CALL Journal, 3, (1-2), 59-80. (10 May 2021) < https://pdfs. semanticscholar.org/1563/7c81207d231e2fc4bbe4176e4435f9f728c9. pdf $>$.

Afshari, M., S. Ghavifekr, S. Siraj and D. Jing (2013). Students' Attitudes towards Computer-assisted Language Learning. Procedia - Social and Behavioral Sciences, 103 (2013), 852-859.

Ali Ghufron, M. and F. Nurdianingsih (2021). Flipped Classroom Method with Computer-assisted Language Learning (CALL) in EFL Writing Class. International Journal of Learning, Teaching and Educational Research, 29 (1), 120-141. (10 May 2021) <https://www.ijlter.org/ index.php/ijlter/article/view/3101>. 
Al-Shammari, M. H. (2007). Saudi English as a Foreign Language Learners' Attitudes toward Computer-Assisted Language Learning. (Unpublished doctoral dissertation). Morgantown: West Virginia University. (10 May 2021) <https://researchrepository.wvu.edu/cgi/viewcontent. cgi article $=5323 \&$ context $=$ etd $>$.

Asrifan, A., C. T. Zita, K. J. Vargheese, T. Syamsu and M. Amir (2020). The Effects of CALL (Computer assisted language learning) toward the Students' English Achievement and Attitude. Journal of Advanced English Studies, 3 (2), 94-106. (10 May 2021) <http://sastra.unifa. ac.id/journal/index.php/jes/article/view/88>.

Bani-Hani A. N. (2014). Benefits \& Barriers of Computer Assisted Language Learning and Teaching in the Arab World: Jordan as a Model. Theory and Practice in Language Studies, 4 (8), 1609-1615. (10 May 2021) <http://www.academypublication.com/issues/past/ tpls/vol04/08/11.pdf $>$.

Basheer, B. (2013). The Impact of Using Technology in Teaching English as a Second Language, English Language and Literature Studies, Canadian Center of Science and Education, 3 (1), 111-116.

Baskaran, L. and C. P. Shafeeq (2015). ESL Teachers' Perceptions of CALL Integration in ELT. International Journal on Studies in English Language and Literature, 3 (5), 63-74. (10 May 2021) < https://www. arcjournals.org/pdfs/ijsell/v3-i5/8.pdf $>$.

Beatty, K. (2010). Computer Assisted Language Learning. London: Longman. Bontha R. U. (2016). Student Reflections on Computer-Assisted Learning with Special Reference to their Course Books. The Journal of Teaching English for Specific and Academic Purposes. 4 (1), 161-170. (10 May 2021) < http://espeap.junis.ni.ac.rs/index.php/espeap/article/view/314> .

Chapelle, C. A. (2003). English Language Learning and Technology. Amsterdam: John Benjamins. (10 May 2021) < https://doi. org/10.1075/11lt.7>.

Chapelle, C. A. (2010). The Spread of Computer-assisted Language Learning. Language Teaching, 43 (1), 66-74. DOI: 10.1017/ S0261444809005850

Davies, G., S. E. K. Otto and B. Rüschoff (2017). Historical Perspectives on CALL. In: C. A. Chapelle and S. Sauro (eds.), The Handbook of Technology and Second Language Teaching and Learning, Hoboken: John Wiley and Son, 19-38. 
Delibegović N. and A. Hasanspahić (2020). Computer Assisted Language Learning in English Language Classrooms in Bosnia and Herzegovina. ExELL (Explorations in English Language and Linguistics), 8 (1), 14-46. DOI: 10.2478/exell-2020-0012

Demirdöken, G. (2019). A Need Analysis Study: Do Students Really Want to Share Their Desks with Technology? Universal Journal of Educational Research. 7(12), 2699-2704. DOI: 10.13189/ujer.2019.071217

Đorđević J. (2020). Improved Understanding of Meaning of Modal Verbs in Legal English and Increased Motivation through Computer Assisted Language Learning. Iberica 39 (2020), 295-318. (10 May 2021) <http://www.aelfe.org/documents/39_12_IBERICA.pdf.>.

Đorđević, J. P. and S. N. Blagojević (2017). Project-based Learning in Computer-assisted Language Learning: an Example from Legal English. Nasleđe, Journal of Language, Literature, Arts and Culture, XIV (36), 247-259. (10 May 2021) <https://scindeks-clanci.ceon.rs/data/ pdf/1820-1768/2017/1820-17681736247D.pdf > .

Eberhard, D. M., G. F. Simons and D. C. Fennig. (eds.). (2020). Ethnologue: Languages of the World. Twenty-third edition. Dallas, Texas: SIL International. Online version: www.ethnologue.com.

Farahnia, S. and A. Khodi (2017). Computer Assisted Vocabulary Instruction: A Case of Applying PowerPoint Presentation into Iranian EFL Classes. RELP, 5 (1), 73-80. (10 May 2021) < http://relp.khuisf. ac.ir/article_533648_ca6ce6e7ccb2479a77b375abe6d6b2ef.pdf > .

Foroozesh-nia, S. (2015). Overview of the Significance of Different Learner Characteristics in Computer-Based Language Learning Environment. In: Rahimi, M. (ed.), Handbook of Research on Individual Differences in Computer-assisted langugage learning, Hershey: IGI Global, 1-24.

Ghorbani N. and S. Ebadi (2020). Exploring Learners' Grammatical Development in Mobile Assisted Language Learning. Cogent Education, 7(1), 1-14. (10 May 2021) <https://doi.org/10.1080/233118 6X.2019.1704599>.

Hubbard, P. (2009). Computer Assisted Language Learning: Vol 1 (Critical Concepts in Linguistics). London: Routledge.

Ismaili, M. (2014). Integrating CALL into the EFL Classroom. The Journal of Teaching English for Specific and Academic Purposes. 2, (4), 697-702. (10 May 2021) <http://espeap.junis.ni.ac.rs/index.php/espeap/ article/view/142/123>. 
Kao, P. and S. Windeatt (2014). Low-achieving Language Learners and SelfDirected Multimedia Environments: Transforming Understanding. In: J. Son (ed.), Computer-Assisted Language Learning: Learners, Teachers and Tools, Newcastle: Cambridge Scholars Publishing, 1- 21. (10 May 2021) <file:///C:/Users/User/Downloads/Computer\%20Assisted\%20 Language\%20Learning\%20by\%20Jeong\%20Bae\%20Son\%202014. pdf $>$.

Kern, R., P. Ware and M. Warschauer (2008). Network-based Language Teaching. In: N. Van Deusen-Scholl and H. Hornberger (eds.), Encyclopedia of Language and Education, 2nd Edition, Volume 4: Second and Foreign Language Education, Switzerland: Springer, 281-292. (10 May 2021) < http://education.uci.edu/uploads/7/2/7/6/72769947/ network-based.pdf $>$.

Kremenska, A. (2007). Measuring Student Attitudes to Computer Assisted Language Learning, CompSysTech'2007, Sofia, ACMBUL, IV. 5-1-6.

Larsen-Freeman, D. (2001). Individual Cognitive /affective learner Contributions and Differential Success in Second Language Acquisition. In: M. P. Breen (ed.), Learner contributions to language learning: new directions in research, London: Pearson Education, 12-24.

Levy, M. (1997). Computer Assisted Language Learning, Context and Conceptualization. Clarendon Press, Oxford: UK.

Lockley, T. and L. Prominitz-Hayashi (2012). Japanese University Students' CALL Attitudes, Aspirations and Motivations. CALL-EJ, 13 (1), 1-16. (10 May 2021) <http://callej.org/journal/13-1/Lockley_PromnitzHayashi_2012.pdf $>$.

Patton, M. Q. (2014). Qualitative Evaluation and Research Methods. London: SAGE Publications.

Paul, A. K. (2020). Integrating CALL into English Language Learning: Bangladeshi College Students Perceptions and Challenges. Journal of English Education and Teaching, 4 (1), 499-515. (10 May 2021) $<$ https://ejournal.unib.ac.id/index.php/JEET/article/view/12432>.

Rachmawati D. L., D. Fadhilawati and S. Setiawan (2020). The Implementation of Computer-Assisted Language Learning (CALL) in the EFL Setting: A Case Study in a Secondary School in Indonesia. English Teaching Journal: A journal of English Literature, Linguistics, and Education, 8 (2), 91-102. (10 May 2021) < http://e-journal.unipma. ac.id/index.php/ETJ/article/view/7159>. 
Rahimi, M. (ed). (2015). Handbook of Research on Individual Differences in Computer-assisted langugage learning. Hershey: IGI Global.

Sadaghatkar, M. (2018). The Effect of Computer-Assisted Language Learning (CALL) on Immediate and Delayed Retention of Vocabulary in General English Course. International Journal of Applied Linguistics and Language IJALEL, 7 (1), 231-238. (10 May 2021) < https://www. journals.aiac.org.au/index.php/IJALEL/article/view/3979>.

Shafaei, A. (2012). Computer Assisted Learning: A Helpful Approach in Learning English. Frontiers of Language and Teaching, 3, 108-115. (10 May 2021) <https://www.academia.edu/2365227/Computer Assisted_Learning_A_Helpful_Approach_in_Learning_English $>$.

Stickler, U. and R. Hampel (2015). Qualitative Research in CALL. CALICO Journal, 32 (3), Qualitative Research in CALL. Published by: Equinox Publishing Ltd, 380-395. (10 May 2021) <https://dx.doi. org/10.1558/cj.v32i3.27737>.

Tafazoli, D., P. E. Gomez and A. C. Huertas (2018). A Cross-cultural Study on the Attitudes of ESL Students towards CALL. Teaching English with Technology, 18 (2), 34-68. (10 May 2021) < ed.gov/?id=EJ1177704>.

Triandis, H. C. (1980). Values, Attitudes, and Interpersonal Behavior In: H. E. Howe and M. M. Page (eds.), Nebraska Symposium on Motivation 1979, University of Nebraska Press, Lincoln, 195-259.

Tsintavi, M. (2017). Students' Attitudes and Perceptions towards ComputerAssisted Language Learning. Journal of Applied Linguistics and Language Research, 4 (3), 65-93. (10 May 2021) <http://www.jallr.com/index. $\mathrm{php} / \mathrm{JALLR} / \mathrm{article} / \mathrm{view} / 547>$.

Vasbieva G. D. and V. N. Saienko (2018). Exploring Students' Perception and Efficiency of Technology-mediated ESP Teaching. Xlinguae, 11 (1XL), 127-1137. (10 May 2021) <http://www.xlinguae.eu/files/ XLinguae1xl_2018_11.pdf $>$.

Vukićević-Đorđević, LJ. (2015). Emerging Technologies: Does It Feel Like Learning? The Journal of Teaching English for Specific and Academic Purposes, 3 (3), 483-497. (10 May 2021) <http://espeap.junis.ni.ac. rs/index.php/espeap/article/view/263>.

Warschauer, M. (1996). Computer Assisted Language Learning: An Introduction. In S. Fotos (ed.), Multimedia language teaching, Tokyo: Logos International, 3-20. 
Warschauer, M. (2000). The Death of Cyberspace and the Rebirth of CALL. English teachers' Journal. "CALL for the 21st Century" IATEFL and ESADE conference, 61-67. (10 May 2021) <http://education.uci. edu/uploads/7/2/7/6/72769947/cyberspace.pdf $>$.

Wiebe, G. and K. Kabata (2010). Students' and Instructors' Attitudes toward the Use of CALL in Foreign Language Teaching and Learning, Computer Assisted Language Learning, 23 (3), 221-234. DOI: 10.1080/09588221.2010.486577

Yang, Y. (2010). Computer-assisted Foreign Language Teaching: Theory and Practice. Journal of Language Teaching and Research, 1 (6), 909-912. DOI:10.4304/jltr.1.6.909-912

Zhang. S. (2011). Attitudes of ESL Students toward the Use of ComputerAssisted Language Learning (call) in a University in China. (Unpublished doctoral dissertation). Texas: A \& M University-Commerce. (10 May 2021) < https://www.proquest.com/docview/884796731>.

Received: 19 August 2021

Accepted for publication: 23 September 2021 


\title{
Appendix
}

Questionnaire on engineering students' attitudes towards

\section{CALL in EFL}

\author{
Section 1 - Personal information
}

1. What are you majoring in at Faculty of Technical Sciences Čačak?
a) Electrical Engineering
b) Information Technology
c) Mechanical Engineering/Informatics
d) Graphic Technology
e) Production Management and Ecology

2. What's your gender? - male/female/other

3. How old are you? - younger than 20/between 20-25/over 25

\section{Section 2 - Questions on CALL}

1. I use CALL for learning English - 1 (never), 2 (rarely), 3 (sometimes), 4 (often), 5 (always)

2. When I need grammar instruction or a world translation I use the Internet - 1 (never), 2 (rarely), 3 (sometimes), 4(often), 5 (always)

3. I find the answer I am looking for on the Internet on a language learning application - 1 (never), 2 (rarely), 3 (sometimes), 4(often), 5 (always)

4. I believe I can improve my English with CALL. (yes/no)

5. I have more trust in my teacher than the information gained online.(yes/no)

6. The type of CALL instruction I enjoy most is... (choose max 3):
a) YouTube
b) Social Networks (Instagram, Facebook, Twitter)
c) mobile phone apps
d) websites for learning English
e) multimedia for learning English
f) games and quizzes on the Internet
g) newspapers articles and blogs

7. I enjoy using computers (phones) for learning English in classes (at the university). (yes/no) 
8. I enjoy using computers (phones) for learning English at home (or elsewhere). (yes/no)

9. I am more motivated to engage in self-study if the content is presented as a computerized instruction (than in the traditional way). (yes/no)

10. I am more anxious or afraid not to make a mistake in a faceto-face class compared to making mistakes in CALL instruction. (yes/no)

\section{Section 3 - Questions on englit.net}

1. I am more motivated to engage in self-study if I use the website englit.net. (yes/no)

2. The website englit.net is helpful for providing access to the materials I need tor exam preparation or homework assignments. (yes/no)

3. I would add these sections to the englit.net webisite:
a) quizzes and games
b) chat
c) forum
d) video lectures
e) audio lectures

4. What I like most about the website englit.net is:
a) practice
b) past exams
c) essays and blogs
d) material availability $24 / 7$
e) lectures on grammar rules
f) video content
g) Twitter and Instagram feed

5. The website englit.net helps me adapt the pace of learning to my personal needs (which lectures to study, when, how much). (yes/ no) 